
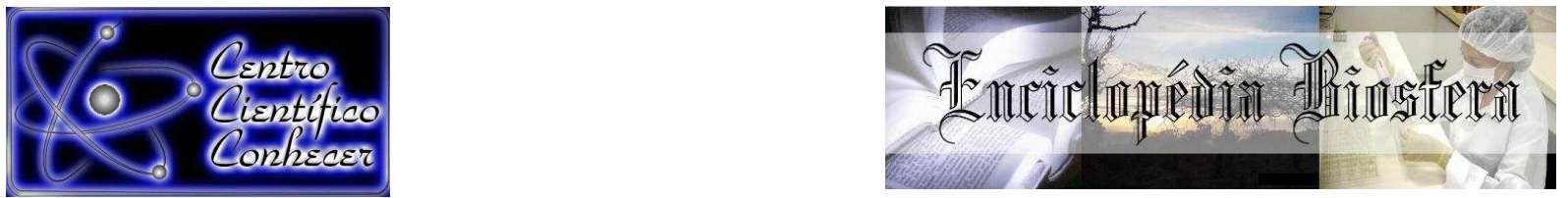

\title{
FOLLICLE POPULATIONS IN MARE OVARIES: FROM PREANTRAL TO PREOVULATORY FOLLICLES
}

\begin{abstract}
Ellen Cristina Rivas Leonel ${ }^{1}$, Viviane Bento-Silva ${ }^{2}$, Eliane Vianna Costa e Silva ${ }^{3}$, Carmem Estefânia Serra Neto Zúccari ${ }^{2}$

${ }^{1}$ Laboratory of Microscopy and Microanalysis, Department of Biology, Institute of Biosciences, Humanities and Exact Sciences, São Paulo State University (UNESP), São José do Rio Preto, São Paulo, Brazil.

${ }^{2}$ Reproduction Biotechnology Laboratory, School of Veterinary Medicine and Animal Science, Federal University of Mato Grosso do Sul. Avenida Senador Felinto Müller, 2443, Campo Grande, Mato Grosso do Sul, Brazil. (carmem.zuccari@ufms.br) ${ }^{3}$ Animal Reproduction Laboratory, School of Veterinary Medicine and Animal Science, Federal University of Mato Grosso do Sul. Avenida Senador Felinto Müller, 2443, Campo Grande, Mato Grosso do Sul, Brazil
Recebido em: 08/09/2015 - Aprovado em: 14/11/2015 - Publicado em: 01/12/2015 DOI: http://dx.doi.org/10.18677/Enciclopedia_Biosfera_2015_162

ABSTRACT

The purpose of this study was to describe morphological and quantitative aspects of preantral and antral follicles in the equine ovary. Six ovaries were collected from necropsied mares and sliced lengthwise parallel to the ovulation fossa. The slices were fixed and processed for histological evaluation under light microscopy. Preantral follicles were classified according to developmental stage and as morphologically normal or degenerated. Also, another 183 ovaries were obtained from an abattoir. From these ovaries, antral follicles were measured, punctured and oocytes evaluated. Oocyte recovery rates were calculated for each follicle size category. A total of 490 preantral follicles were examined. Primary follicles were in greater number than primordial follicles. No secondary follicles were identified. A total of 518 antral follicles were punctured and evaluated. Total oocyte recovery rate from antral follicles was 47.6. In conclusion, preantral follicles consist of a scarce source in the equine ovary. Antral follicles oocyte recovery rate was higher for smaller-diameter antral follicles.
\end{abstract}

KEYWORDS: antral follicle, morphology, mare, ovary, preantral follicle 


\title{
POPULAÇÕES FOLICULARES EM OVÁRIOS EQUINOS: DOS FOLÍCULOS PREANTRAIS AOS ANTRAIS
}

\begin{abstract}
RESUMO
O objetivo do presente experimento foi descrever aspectos morfológicos e quantitativos da população folicular pré-antral e antral do ovário equino. Seis ovários foram coletados após necropsia e fragmentados longitudinalmente em paralelo à fossa ovulatória. Os fragmentos foram fixados e processados histologicamente para avaliação sob microscopia de luz. Os folículos pré-antrais foram classificados como morfologicamente normais ou degenerados e de acordo com o estágio do desenvolvimento. Em adição, outros 183 ovários foram obtidos em frigorífico equino. Nestes ovários, foram avaliados os folículos antrais. Os mesmos foram medidos e puncionados para a caracterização morfológica dos ovócitos. As taxas de recuperação ovocitária foram calculadas para cada categoria de folículos antrais. No primeiro grupo de ovários, um total de 490 folículos pré-antrais foram avaliados. Os folículos primários foram os mais frequentes, sendo encontrados em maior quantidade do que folículos primordiais. Folículos secundários não foram identificados. Com relação ao segundo grupo de ovários, 518 folículos antrais foram avaliados e puncionados. A taxa de recuperação ovocitária total foi de 47,6. Pôde-se concluir que os folículos pré-antrais consistem de uma fonte limitada de folículos no ovário equino. Quanto aos folículos antrais, a taxa de recuperação ovocitária foi maior para folículos de menor diâmetro.
\end{abstract}

PALAVRAS-CHAVE: égua, folículo antral, folículo pré-antral, morfologia, ovário

\section{INTRODUCTION}

Akin to some species, equine ovaries are both endocrine-secreting, among other hormones, $17 \beta$-estradiol-and exocrine-generating germinative female cells: the oocytes [BRINSKO et al., 2011]. They are located ventrally to the 4th or 5th lumbar vertebra and most of their surface is covered by peritoneum, except at the hilus, the small portion where vessels and nerves are inserted [GINTHER, 1992].

The equine ovary is peculiar in that, unlike other mammalian ovaries, its germinal surface, where follicles and oocytes are found, is located at the organ's central portion, while its conjunctive tissue and vessels are found in the external layer. Consequently, ovulation takes place only in the ovulation fossa, which begins to develop in early gestation, when the ovarian cortical layer, where preovulatory follicles (POFs) will be present, starts to contract and invaginate [WALT et al., 1979].

Of the several different cell types found in the ovarian structure, conjunctive tissue cells, oocytes, and both granulosa and theca cells are the most important. Mammalian ovaries have a reserve pool of germ cells: the oocytes included in preantral follicles (PAFs). These structures are to ensure reproduction capacity throughout the reproductive life of females, conserving oocytes until ovulation time [SILVA-SANTOS et al., 2011]. Because PAFs are available in great numbers, their use is advantageous for 
the preservation of genomic material and development of new individuals from these oocytes.

POFs have been extensively used in breeding protocols. Employing POFs in biotechniques such as artificial insemination [AVANZI et al., 2015], embryo transfer [PESSOA et al., 2011], intracytoplasmic injection of spermatozoa [SESSIONSBRESNAHAN et al., 2014], and use of sexed semen [SAMPER et al., 2012] has led to considerable advancements in the areas of reproductive physiology, gametogenesis, and embryogenesis [AURICH, 2012].

Importantly, these biotechniques have not only had a marked impact on the quality of genetic resources from livestock species, but have also led to the creation of germplasm banks, which allow genetic material from endangered species to be preserved [SIMON et al., 2012].

With regard to POFs, oocyte recovery rate and oocyte quality can be affected by several factors, including the recovery technique adopted, follicle size, and time elapsed between puncture and beginning of culture. Oocytes can be obtained from slaughtered animals [SUTTON-MCDOWELL et al., 2014], by ultrasound-guided ovarian puncture in vivo, [IACONO et al., 2014] or by laparoscopy-assisted methods [BESENFELDER et al., 2012].

However, relevant information on early folliculogenesis, and likewise about mare follicle population, is scarce, although PAFs have been quantified and characterized in other mammalian species. Follicle population per ovary is highly variable across species, having been estimated at 35000 in caprines [LUCCl et al., 1999] and 160000 in ovines [AMORIM et al., 2000]. PAFs can be frozen and/or cultured in vivo or in vitro and developed until a suitable stage when in vitro fertilization (IVF) can be performed.

In equines, oocyte recovery followed by IVF is crucial for commercial embryo transfer programs. Although frozen oocytes can be kept in banks for future fertilization, the retrieval and viability of maintaining these cells pose a considerable challenge for IVF and embryo transfer programs [THARASANIT et al., 2006].

Although the morphology and viability of normal cumulus-oocyte complexes have been investigated [CURCIO et al., 2014; FOSS et al., 2013], scant data are available on the effect of follicular diameter on oocyte recovery rates. Abattoirs are a promising option for obtaining equine oocytes in great numbers, since gonads would otherwise be discarded [DELL'AQUILA et al., 1997]. Another advantage is that mares sent to abattoirs have not been subjected to superovulation procedures or other reproductive treatments, thereby allowing ovaries to be evaluated under normal physiological conditions. Also, characterization and quantification of equine follicles can help improve methods of isolating PAFs for in vitro culture, as well as POF puncture in IVF.

The purposes of this study were to describe morphological and quantitative aspects of the preantral follicle population in equine ovaries and to evaluate the effect of follicular diameter on the recovery rates of oocytes harvested from equine ovaries obtained from an abattoir. 


\section{MATERIAL AND METHODS}

Equine ovaries $(n=189)$ were collected from 183 mares slaughtered in an abattoir and from six mares subjected to euthanasia in a veterinary hospital due to trauma or colic syndrome. Mare ages (range 2-23 years) were determined based on dental arcade features. One animal was a fetus with a gestational age of 7 months. All adult mares died during the ovulatory season. All animals were crossbred.

\subsection{Experiment 1}

The ovaries obtained from necropsied euthanized animals (October, 2026'34"S, 5438'47'W) were collected immediately after opening the abdominal cavity and then sent to the laboratory for determinations of weight and measurements. For evaluation of PAFs, the ovaries were sliced lengthwise into $3 \mathrm{~mm}$-thick fragments, parallel to the ovulation fossa. During manipulation, the fragments were kept in phosphate buffer saline (PBS) at $38{ }^{\circ} \mathrm{C}$ and fixed in Carnoy's fluid (60\% ethanol, 30\% chloroform, and $10 \%$ glacial acetic acid) for $12 \mathrm{~h}$. Fragments were then processed for histology, as follows: serial dehydration in ethanol $(70 \%, 80 \%, 90 \%$, and $100 \%)$; clarification in xylene; paraffin embedding; and transection in a microtome $(5 \mu \mathrm{m}$ thickness). The slices were cut every $50 \mu \mathrm{m}$ to avoid counting the same follicle twice and then subjected to periodic acid-Schiff (PAS) reaction to allow identification of the basement membrane. For evaluation of PAF morphology, only follicles having the oocyte nucleus in the slice being observed were classified as primordial (one flattened granulosa cell layer) or primary (one cuboidal granulosa cells layer).

The follicles were also classified as morphologically normal or degenerated, based on granulosa cell features (morphology and density), nucleus characteristics, basement membrane integrity, and presence of pyknotic bodies (Table 1).

Descriptive statistics were employed for data treatment.

2.2 Experiment 2

The ovaries obtained from the abattoir (January, 2325 '38"S, 5156 '15"W) were collected from the inspection table, placed in containers with $0.9 \%$ physiologic saline plus penicillin (100 Ul/mL) and streptomycin $(50 \mathrm{mg} / \mathrm{mL})$, and sent to the laboratory, where the antral follicles detected on the ovarian surface were counted, measured, and categorized according to diameter as Class A ( $\leq 15 \mathrm{~mm})$, Class B $(20-30 \mathrm{~mm})$, or Class C ( $\geq 35 \mathrm{~mm}$ ). Oocytes were harvested by follicle puncture performed with an 18G needle attached to a syringe. The follicular fluid was added to phosphate buffer saline (PBS), $10 \%$ fetal calf serum (FCS), penicillin $(100 \mathrm{Ul} / \mathrm{mL})$, and streptomycin $(50 \mu \mathrm{g} / \mathrm{mL})$. The resulting mixture was decanted in a test tube, the supernatant discarded, and the cells transferred to a Petri dish for oocyte evaluation under a stereoscopic microscope.

Data were subjected to ANOVA. Tukey's test was employed to compare means. Differences were considered significant for values of $p<0.05$. 
TABLE 1. Morphological classification of equine preantral follicles according to histological features (normal or degenerated) after periodic acid-Schiff (PAS) reaction

\begin{tabular}{cl}
\hline Classification & \multicolumn{1}{c}{ Morphological features } \\
\hline Normal (N) & $\begin{array}{l}\text { Intact oocyte } \\
\text { Organized granulosa cells and non- } \\
\text { degraded nucleus }\end{array}$ \\
\hline $\begin{array}{c}\text { Type 1 } \\
\text { degeneration }\end{array}$ & $\begin{array}{l}\text { Contracted oocyte } \\
\text { Pyknotic nucleus } \\
\text { Non-degraded basement membrane }\end{array}$ \\
T1A & $\begin{array}{l}\text { Contracted oocyte } \\
\text { Pyknotic nucleus } \\
\text { Degraded basement membrane }\end{array}$ \\
\hline Type 2 & $\begin{array}{l}\text { Pyknotic oocyte } \\
\text { Granulosa cell disorganization } \\
\text { degeneration }\end{array}$ \\
T2A & $\begin{array}{l}\text { Pyknotic oocyte } \\
\text { Granulosa cell disorganization } \\
\text { Degraded basement membrane }\end{array}$ \\
\hline T2B & Ponded basement membrane \\
\hline
\end{tabular}

\section{RESULTS AND DISCUSSION}

Of the 189 ovaries investigated, $168(88.88 \%)$ had several antral follicles on their surface. From these 168, 70 (41.66\%) showed corpora lutea. Mean ovarian length, width, and thickness $(\mu \mathrm{m})$ were $55.74 \pm 12.95,41.97 \pm 11.02$, and $35.17 \pm 13.39$, respectively. Mean weight was $37.03 \pm 31.26 \mathrm{~g}$.

Of the 490 PAFs counted in experiment 1, 199 were primordial $(40.6 \%$; Table 2) and 291 primary (59.4\%; Table 3) (Figure 1) -i.e., their numbers were very small in both cases, a large variation in the numbers of follicles of each class was evident across animals, and even an absence of primordial follicles occurred in the oldest mare (23 years). This caused most standard deviation values to be higher than the means (Tables 2 and 3). 


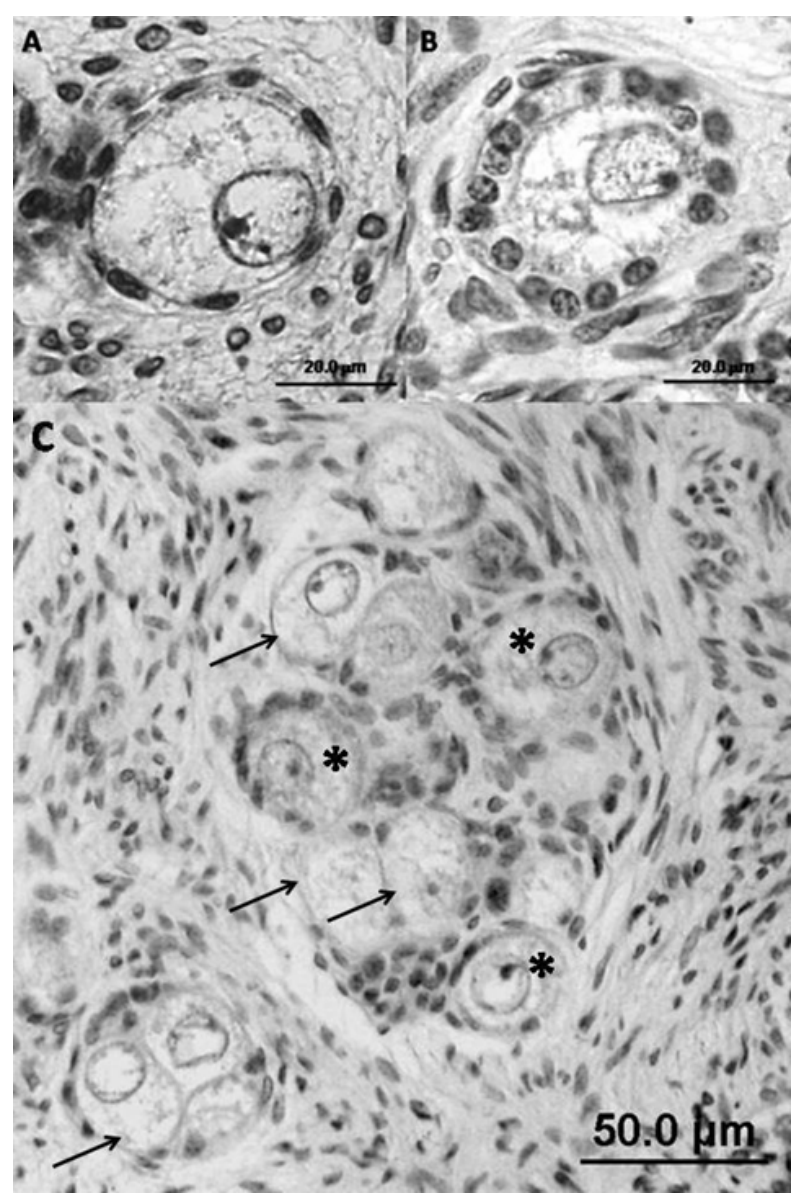

FIGURE 1. Normal equine preantral follicles: primordial follicle (A); primary follicle (B); pool of follicles (C) with primordial (arrows) and primary follicles (asterisks). 
TABLE 2. Distribution of primordial follicles per equine ovary, by morphological class

\begin{tabular}{cccccccc}
\hline \multirow{2}{*}{ Animal } & Age & \multicolumn{7}{c}{ Primordial follicles } & \multirow{2}{*}{ Total } \\
\cline { 3 - 6 } & (years) & Normal & T1A & T1B & T2A & T2B & \\
\hline 1 & 23 & 0 & 0 & 0 & 0 & 0 & 0 \\
2 & 18 & 0 & 0 & 1 & 0 & 8 & 9 \\
3 & 14 & 1 & 0 & 0 & 0 & 13 & 14 \\
4 & 8 & 0 & 6 & 0 & 5 & 3 & 14 \\
5 & 2 & 5 & 11 & 0 & 13 & 47 & 76 \\
6 & 0.58 & 2 & 11 & 0 & 45 & 28 & 86 \\
\hline \multicolumn{2}{c}{ Total } & 8 & 28 & 1 & 63 & 99 & 199 \\
\hline \multicolumn{2}{c}{ Mean } & 1.333 & 4.666 & 0.166 & 16.5 & 10.5 & 33.166 \\
\multicolumn{2}{c}{ SD } & 1.966 & 5.428 & 0.408 & 17.896 & 17.649 & 37.536 \\
\hline
\end{tabular}

TABLE 3. Distribution of primary follicles per equine ovary, by morphological class

\begin{tabular}{|c|c|c|c|c|c|c|c|}
\hline \multirow{2}{*}{ Animal } & \multirow{2}{*}{$\begin{array}{c}\text { Age } \\
\text { (years) }\end{array}$} & \multicolumn{5}{|c|}{ Primary follicles } & \multirow{2}{*}{ Total } \\
\hline & & Normal & T1A & $\mathrm{T} 1 \mathrm{~B}$ & T2A & T2B & \\
\hline 1 & 23 & 0 & 0 & 0 & 0 & 5 & 5 \\
\hline 2 & 18 & 0 & 0 & 0 & 2 & 2 & 2 \\
\hline 3 & 14 & 0 & 1 & 0 & 2 & 6 & 7 \\
\hline 4 & 8 & 0 & 1 & 0 & 4 & 6 & 12 \\
\hline 5 & 2 & 10 & 18 & 5 & 8 & 91 & 137 \\
\hline 6 & 0.58 & 4 & 13 & 0 & 10 & 66 & 128 \\
\hline \multicolumn{2}{|c|}{ Total } & 14 & 33 & 5 & 176 & 26 & 291 \\
\hline \multicolumn{2}{|c|}{ Mean } & 2.333 & 5.5 & 0.833 & 4.333 & 29.333 & 48.5 \\
\hline \multicolumn{2}{|c|}{ SD } & 4.082 & 7.918 & 2.041 & 3.881 & 38.923 & 65.209 \\
\hline
\end{tabular}

Identifying PAFs in situ in equine ovaries is a more complex task than in other mammals. LUCCI et al. [2004], employing cryopreservation techniques, identified 4901 follicles in bovine ovaries. In mares, however, the germinative epithelium is limited to the ovulation fossa, yet PAFs can be found in the entire ovarian stroma in groups of 2 to 7 follicles [SZLACHTA TISCHNER, 1998], although they more often occur singly, as observed in the present experiment. These factors contribute to the difficulties experienced locating follicles in the equine ovary, given the size of this gonad.

In mares, DRIANCOURT et al. [1982] found a higher number of PAFs (35 950 of them primordial and 100 primary or secondary) per ovary. By contrast, mares in the present study had a higher percentage of primary than primordial follicles. Low percentages of primordial follicles have also been observed in other species. Examining elephant ovaries, STANSFIELD et al. [2011] found that the ovarian follicle reserve harbored $75 \%$ primary follicles, but only $2 \%$ primordial follicles. 
In older mammals, low percentages of follicles may be due to atresia or apoptosis [GINTHER, 1992], or to oocyte consumption along the lifespan. Follicle populations are not renewed in most mammalian species, including mares-although rare instances have been described in humans [BURKOVSKY et al., 2004].

In the present study, secondary follicles were not observed among growing follicles, at any stage. Secondary follicles are typically found in small numbers, given their short lifespan [MÜLLER et al., 2009]. Evaluating PAF populations in situ in mare ovaries, HAAG et al. [2013] found only primordial and primary follicles, similarly to the present study.

Among the 168 ovaries in the second experiment, 518 antral follicles were punctured. Follicle categorization was distributed as follows: class A, 61.9\% (321); class $\mathrm{B}, 26.8 \%$ (139); class C, $11.1 \%(58)$. Stratified by category, recovery rates were as follows: class A, $53.5 \%$; class $B, 35.9 \%$; class C, $43.1 \%$. The overall oocyte recovery rate was $47.6 \%$. Mean number of follicles per ovary was 3.0. Mean numbers in each class were as follows: class A, 1.9 (321/518); class B, 0.8 (139/518); class C, 0.3 (58/518). Mean number of oocytes obtained by puncture was 1.47 per ovary. Relationships between follicle diameters and oocyte recovery rates are shown in Table 4.

TABLE 4. Rates of oocyte recovery from equine ovaries, by follicular diameter

\begin{tabular}{lccc}
\hline \multirow{2}{*}{ Variables } & \multicolumn{3}{c}{ Follicular diameter } \\
\cline { 2 - 4 } & $\begin{array}{c}\mathrm{A}(\leq 15 \\
\mathrm{mm})\end{array}$ & $\begin{array}{c}\mathrm{B}(20-30 \\
\mathrm{mm})\end{array}$ & $\begin{array}{c}\mathrm{C}(\geq 35 \\
\mathrm{mm})\end{array}$ \\
\hline $\begin{array}{l}\text { Punctured } \\
\text { follicles (\%) }\end{array}$ & $61.9^{\mathrm{a}}$ & $26.8^{\mathrm{b}}$ & $11.1^{\mathrm{c}}$ \\
$\begin{array}{l}\text { Oocyte recovery } \\
\text { Ooyy }\end{array}$ & $53.5^{\mathrm{a}}$ & $35.9^{\mathrm{b}}$ & $43.1^{\mathrm{a}, \mathrm{b}}$
\end{tabular}

$(\%)$

${ }^{a-c}$ Different letters in same row indicate significant differences $(p<0.05)$.

Ovarian sizes and corpus luteum percentages (41.66\%) were consistent with the season of ovary collection and the corresponding reproductive cycle stage in mares.

In the present investigation, the rate of aspiration was higher for class $A$ antral follicles, followed by classes B and C-results corroborating those of HINRICHS et al. [1991], who found the proportion of viable follicles to rise with increasing follicle size. ZÚCCARI et al. [2013] observed mean follicle populations, evaluated by rectal palpation, of $2.84,1.15$, and 1.15 for classes A, B, and C, respectively (employing the same criteria for class definition as the present study).

Oocyte recovery rate was 47.6 in the present investigation, lower than the $54 \%$ obtained by JACOBSON et al. [2010], who employed hormonal manipulation to cycle mares.

In mares, the oocyte-cumulus complex is attached to the follicle wall by a wide base [GINTHER, 1992], contrasting with other species, in which cumulus cells exhibit a pedunculated structure-a histological feature likely to promote stronger oocyte 
adhesion, resulting in lower recovery rates, especially when collection involves aspiration.

Follicle external diameter has an effect on oocyte quality and oocyte developmental competence after maturation, fertilization, and in vitro culture [GOUDET et al., 1997]. Experiments conducted on different species have revealed that large follicle size may be related to increased percentages of fertile oocytes during IVF in bovines swine [LUCAS et al., 2003], and humans [TEISSIER et al., 2000].

In the present investigation, Class A ovaries contained larger follicle populations available for oocyte aspiration. Recovery rates were higher for class $A$ than for class $B$ follicles. For IVF protocols, two issues have yet to be resolved: efficient methods for both oocyte recovery and sperm preparation for in vitro fertilization.

\section{CONCLUSION}

In conclusion, mare germ cells in the ovarian stroma exhibit a peculiar organization that differs from most mammalian species. Follicles can be found in groups or isolated. PAFs occur in small numbers. Primary follicles occur at higher percentages. Secondary follicles were absent. Antral follicles measuring $15 \mathrm{~mm}$ or less constituted the largest population available for oocyte aspiration, with higher recovery rates.

This investigation was supported by the Brazilian Council for Scientific and Technological Development (CNPq). No conflicts of interest exist that may be detrimental to the impartiality of the research reported.

\section{REFERENCES}

AMORIM, C.A.; LUCCI, C.M.; RODRIGUES, A.P.R.; CARVALHO, F.C.A.; FIGUEIREDO, J.R.; RONDINA, D.; CECCHI, R.; GIORGETTI, A.; MARTINI, A.; GONÇALVES, P.B.D. Quantitative and qualitative analysis of the effectiveness of a mechanical method for the isolation of preantral follicles from ovine ovaries. Theriogenology, v.53, p.1251-62, 2000. Disponível em: <http://www.theriojournal.com/article/S0093-691X(00)00269-7/abstract>. DOI: DOI: http://dx.doi.org/10.1016/S0093-691X(00)00269-7.

AURICH, J.E. Artificial insemination in horses-More than a century of practice and research. Journal of Equine Veterinary Science, v.32, p.458-63. 2012. Disponível em: <http://www.j-evs.com/article/S0737-0806(12)00331-0/abstract>.

DOI: http://dx.doi.org/10.1016/j.jevs.2012.06.011.

AVANZI, B.R; RAMOS, R.S.; ARAUJO, G.H.; FIORATTI, E.G.; TRINCA, L.A.; DELL`AQUA, J.A.JR.; MELO E OÑA, C.M.; ZAHN, F.S.; MARTIN, I., ALVARENGA, M.A.; PAPA, F.O. Fixed-time insemination with frozen semen in mares: is it suitable for poorly fertile stallions? Theriogenology, v.83, p.1389-93, 2015. Disponível em: $<$ http://www.ncbi.nlm.nih.gov/pubmed/?term=Fixed-

time+insemination+with+frozen+semen+in+mares $\% 3 A+i s+i t+$ suitable+for+poorly+fertile +stallions\%3F>. DOI: 10.1016/j.theriogenology.2014.07.007. 
BESENFELDER, U.; HAVLICEK, V.; BREM, G. Role of the Oviduct in Early Embryo Development. Reproduction in Domestic Animals, v. 47, p.156-63, 2012. Disponível em: http://www.ncbi.nlm.nih.gov/pubmed/22827365. DOI: 10.1111/j.14390531.2012.02070.x.

BRINSKO, S.P.; BLANCHARD, T.L.; VARNER, D.D. Manual of Equine Reproduction. St Louis: Elsevier, 2011. 336p.

BURKOVSKY, A.; CAUDLE, M.R.; SVETLIKOVA, M.; UPADHYAYA, NB. Origin of germ cells and formation of new primary follicles in adult human ovaries. Reproduction Biology and Endocrinology, v.2, p.1-30, 2004. Disponível em: <http://www.ncbi.nlm.nih.gov/pmc/articles/PMC420494/>. DOI: 10.1186/1477-7827-220.

CURCIO, B.R.; GASTAL, M.O.; PEREIRA, G.R.; CORCINI, C.D.; LANDIMALVARENGA, F.C.; BARROS, S.S.; NOGUEIRA, C.E.W.; DESCHAMPS, J.C.; GASTAL, E.L. Ultrastructural morphology and nuclear maturation rates of immature equine oocytes vitrified with different solutions and exposure times. Journal of Equine Veterinary Science, v.34, p.632-40, 2014. Discponível em: <http://www.sciencedirect.com/science/article/pii/S073708061300930>.

DOI:10.1016/j.jevs.2013.12.002.

DELL'AQUILA, M.E.; CHO, Y.S.; MINOIA, P.; TRAINA, V.; FUSCO, S.; LACALANDRA, G.M.; MARITATO, F. Intracytoplasmic sperm injection (ICSI) versus conventional IVF on abattoir-derived and in vitro-matured equine oocytes. Theriogenology, v.47, p.1139-56, 1997. Disponível em: http://www.ncbi.nlm.nih.gov/pubmed/16728064. DOI: http://dx.doi.org/10.1016/S0093-691X(97)00095-2.

DRIANCOURT, M.A.; PARIS, A.; ROUX, C.; MARIANA, J.C.; PALMER, E. Ovarian follicular populations in pony and saddle-type mares. Reproduction, Nutrition and Development, v.22, p.1035-47, 1982. Disponível em: $<$ http://www.ncbi.nlm.nih.gov/pubmed/7163613>.

FOSS, R.; ORTIS, H.; HINRICHS, K. Effect of potential oocyte transport protocols on blastocyst rates after intracytoplasmic sperm injection in the horse. Equine Veterinary Journal, v.45, p.39-43, 2013. $\quad$ Disponível em: <http://onlinelibrary.wiley.com/doi/10.1111/evj.12159/abstract>. DOI: 10.1111/evj.12159. GINTHER, O.J. Reproductive anatomy. Wisconsin: Equiservices, 1992, 322p.

GOUDET, G.; BEZARD, J.; DUCHAMP, G.; GERARD, N.; PALMER, E. Equine oocyte competence for nuclear and cytoplasmic in vitro maturation: effect of follicle size and hormonal environment. Biology of Reproduction, v.57, p.232-45,

ENCICLOPÉDIA BIOSFERA, Centro Científico Conhecer - Goiânia, v.11 n.22; p. ${ }^{1330} 2015$ 
1997. Disponível em: < http://www.ncbi.nlm.nih.gov/pubmed/9241036>. DOI: 10.1095/ biolreprod57.2.232.

HAAG, K.T.; MAGALHÃES-PADILHA, D.M.; FONSECA, G.R.; WISCHRAL, A.; GASTAL, M.O.; KING; S.S.; JONES, K.L.; FIGUEIREDO, J.R.; GASTAL, E.L. Equine preantral follicles obtained via the Biopsy Pick-up method: Histological evaluation and validation of a mechanical isolation technique. Theriogenology, v.79, p.735-43, 2013. Disponível em: <http://www.ncbi.nlm.nih.gov/pubmed/23352704>. DOI: 10.1016/j.theriogenology.2012.10.023.

HINRICHS, K. The relationship of follicle atresia to follicle size, oocyte recovery rate on aspiration, and oocyte morphology in the mare. Theriogenology, v.26, p.157-68, 1991. Disponível em: < http://www.ncbi.nlm.nih.gov/pubmed/16726989>. DOI: http://dx.doi.org/10.1016/0093-691X(91)90375-N.

IACONO, E.; MERLO, B.; RIZZATO, G.; MISLEI, B.; GOVONI, N.; TAMANINI, C.; MARI, G. Effects of repeated transvaginal ultrasound-guided aspirations performed in anestrous and cyclic mares on P4 and E2 plasma levels and luteal function. Theriogenology. v.82, p.225-231, 2014. Disponível em: <http://www.ncbi.nlm.nih.gov/pubmed/24780115>. DOI: 10.1016/j.theriogenology.2014.03.025.

JACOBSON, C.C.; CHOI, Y.H.; HAYDEN, S.S.; HINRICHS, K. Recovery of mare oocytes on a fixed biweekly schedule, and resulting blastocyst formation after intracytoplasmic sperm injection. Theriogenology, v.73, p.1116-26, 2010. Disponível em: <http://www.ncbi.nlm.nih.gov/pubmed/20202674>. 10.1016/j.theriogenology.2010.01.013.

LUCAS, X.; MARTÍNEZ, E.A.; ROCA, J.; VÁZQUEZ, J.M.; GIL, M.A.; PASTOR, L.M.; ALABART, J.L. Influence of follicle size on the penetrability of immature pig oocytes for homologous in vitro penetration assay. Theriogenology, v.60, p.659-67. 2003. Disponível em: < http://www.sciencedirect.com/science/article/pii/S0093691X03000773> DOI:10.1016/S0093-691X(03)00077-3.

LUCCI, C.M.; AMORIM, C.A.; RODRIGUES, A.P.R.; FIGUEIREDO, J.R., BÁO, S.N.; SILVA, J.R.V.; SILVA, J.R.V.; GONÇALVES, P.B.D. Study of preantral follicle population in situ and after mechanical isolation from caprine ovaries at different reproductive stages. Animal Reproduction Science, v.56, p.223-36, 1999. Disponível em: <http://www.sciencedirect.com/science/article/pii/S0378432099000457>.

DOI:10.1016/S0378-4320(99)00045-7.

LUCCI, C.M.; KACINSKIS, M.A.; LOPES, L.H.R.; RUMPF, R.; BÁO, S.N. Effect of different cryoprotectants on the structural preservation of follicles in 
frozen zebu bovine (Bos indicus) ovarian tissue. Theriogenology, v.61, p.1101-14, $2004 . \quad$ Disponível

<http://www.sciencedirect.com/science/article/pii/S0093691X03002966>.

DOI:10.1016/j.theriogenology.2003.06.004.

MÜLLER, K.; ELLENBERGER, C.; SCHOON, H.A. Histomorphological and immunohistochemical study of angiogenesis and angiogenic factors in the ovary of the mare. Research Veterinary Science, v.87, p.421-31, 2009. Disponível em: <http://www.sciencedirect.com/science/article/pii/S0034528809000940>.

DOI:10.1016/j.rvsc.2009.04.011.

PESSOA, M.A.; CANNIZZA, A.P.; REGHINI, M.A.S.; ALVARENGA, M.A. Embryo transfer efficiency of Quarter Horse athletic mares. Journal of Equine Veterinary Science, v.31, p.703-5, 2011. Disponível em: <http://www.sciencedirect.com/science/article/pii/S0737080611003820>.

DOI:10.1016/j.jevs.2011.06.001.

SAMPER, J.C.; MORRIS, L.; PEÑA, F.J.; PLOUGH, T.A. Commercial breeding with sexed stallion semen: Reality or fiction? Journal of Equine Veterinary Science, v.32, p.471-4, 2012. Disponível em: <http://www.sciencedirect.com/science/article/pii/S0737080612003462>. DOI:10.1016/j.jevs.2012.06.018.

SESSIONS-BRESNAHAN, D.R.; GRAHAN, J.K.; CARNEVALE, E.M. Validation of a heterologous fertilization assay and comparison of fertilization rates of equine oocytes using in vitro fertilization, perivitelline, and intracytoplasmic sperm injections. Theriogenology, $\quad$ v.82, $\quad$ p.274-82, 2014. Disponível em: <http://www.sciencedirect.com/science/article/pii/S0093691X14001812>. DOI:10.1016/j.theriogenology.2014.04.002.

SILVA-SANTOS, K.C.; SANTOS, G.M.G.; SILOTO, L.S.; HERTEL, M.F.; ANDRADE, E.R.; RUBIN, M.I.B; STURION, L.; MELO-STERZA, F.A.; SENEDA, M.M. Estimate of the population of preantral follicles in the ovaries of Bos taurus indicus and Bos taurus taurus cattle. Theriogenology, v.76, p.1051-7, 2011. Disponível em: <http://www.ncbi.nlm.nih.gov/pubmed/21722949>. DOI: 10.1016/j.theriogenology.2011.05.008.

SIMON, M.A.; GIL-SÁNCHEZ, J.M.; RUIZ, G.; GARROTE, G.; MCCAIN, M.B.; FERNÁNDEZ, L.; LÓPEZ-PARRA, M.; ROJAS, E.A.; ARENAS-ROJAS, R.; DEL REY, T.; GARCÍA-TARDíO, M.; LÓPEZ, G. Reverse of the Decline of the Endangered Iberian Lynx. Consevation Biology, v.26, p.731-6, 2012. Disponível em: <http://www.ncbi.nlm.nih.gov/pubmed/22734818>. $\quad$ DOI: $\quad 10.1111 /$ j.15231739.2012.01871.x. 
STANSFIELD, F.J.; PICTON, H.M.; NÖTHLING, J.A. Early primary-rather than primordial follicles constitute the main follicular reserve in the African elephant (Loxodonta africana). Animal Reproduction Science, v.123, p.112-8, 2011. Disponível em: <http://www.sciencedirect.com/science/article/pii/S0378432010004537>. DOI:10.1016/j.anireprosci.2010.11.003.

SUTTON-MCDOWALL, M.L.; YELLAND, R.; MACMILLAN, K.L.; ROBKER, R.L.; THOMPSON, J.G. A study relating the composition of follicular fluid and blood plasma from individual Holstein dairy cows to the in vitro developmental competence of pooled abattoir-derived oocytes. Theriogenology, v. 82, p.95-103, 2014. Disponível em: <http://www.sciencedirect.com/science/article/pii/S0093691X14001526>.

DOI:10.1016/j.theriogenology.2014.03.011.

SZLACHTA, M.; TISCHNER, M. Distribution, morphology and ultrastructure of preantral follicles in the ovary of the mare. Havemeyer Found Monogr Ser, v.5, p.33-5, 1998.

TEISSIER, M,P,; CHABLE, H.; PAULHAC, S.; AUBARD, Y. Comparison of follicle steroidogenesis from normal and polycystic in woman undergoing IVF: relationship between steroid concentrations, follicle size, oocyte quality and fecundability. Human Reproduction, v.15, p.2471-7, 2000. Disponível em: <http://www.ncbi.nlm.nih.gov/pubmed/11098013>. DOI: 10.1093/humrep/15.12.2471.

THARASANIT T, COLLEONI S, LAZZARI G, COLENBRANDER B, GALLI C, STOUT TAE. Effect of cumulus morphology and maturation stage on the cryopreservability of equine oocytes. Reproduction, v.132, p.759-69, 2006. Disponível em: <http://www.ncbi.nlm.nih.gov/pubmed/17071777>. DOI: 10.1530/rep.1.01156.

WALT, M.L.; STABENFELDT, G.H.; HUGHES, J.P.; NEELY, D.P.; BRADBURY, R. Development of equine ovary and ovulation fossa. Journal of Reproduction and Fertility Supplement, v.27, p.471-7, 1979. Disponível em: <http://www.ncbi.nlm.nih.gov/pubmed/289826>.

ZÚCCARI, C.E.S.N.; BENDER, E.S.C.; SILVA, E.V.C.; SATURNINO, H.M. Eficiência reprodutiva e dinâmica folicular de éguas Campolina de acordo com a condição corporal. Ciência Animal Brasileira, v.14, p.406-12, 2013. Disponível em: <http://www.revistas.ufg.br/index.php/vet/article/view/17693>. DOI: 10.5216/cab.v14i4.17693. 